\title{
Peran Suami Sebagai Educator Pada Pasutri Dalam Melakukan Deteksi Dini Kanker Leher Rahim
}

\author{
Chrisdianti Yulita1, Any Ashari2, Lucky Herawati3 \\ 1Sekolah Tinggi Ilmu Kesehatan Guna Bangsa Yogyakarta \\ ${ }_{2}$ Ummi Khasanah Bantul, Yogyakarta \\ 3Poltekkes Kemenkes Yogyakarta
}

Korespondensi:yulita_chris@yahoo.com

DOI: https://doi.org/10.33859/dksm.v10i2.454

\begin{abstract}
Abstrak
Latar Belakang: Masalah kesehatan perempuan masih menjadi tugas bagi pemerintah dan tenaga kesehatan, terkait tingginya AKI yang salah satunya disebabkan oleh kanker leher rahim. Upaya yang dilakukan untuk mencegah kanker leher rahim yaitu dengan melakukan deteksi dini. Dengan memberikan informasi melalui pendidikan kesehatan pada pasutri untuk memotivasi melakukan deteksi dini.

Tujuan: Tujuan penelitian menganalisis peran suami penderita kanker leher rahim sebagai educator terhadap pengetahuan dan keikutsertaan pasutri dalam melakukan deteksi dini di Puskesmas Karangmojo II dan Semanu I Gunungkidul.

Metode: Metode penelitian yaitu Quasi eksperimen dengan desain pretest and posttest with control group desain. Pemilihan sampel menggunakan teknik simple random sampling sebanyak 42 pasutri untuk kelompok intervensi dan 42 responden untuk kelompok kontrol. Pendidikan kesehatan sebagai intervensi dilakukan oleh suami penderita kanker leher rahim sebagai educator menggunakan buku saku dan kader menggunakan leaflet. Data dianalisis menggunakan uji t-test, chi square, regresi linier, dan binary logistik dengan taraf siginifan $\alpha=0,05$.

Hasil: Hasilnya menunjukkan bahwa peningkatan pengetahuan dan keikutsertaan pada kelompok intervensi lebih besar dibandingkan kelompok kontrol setelah diberikan intervensi $(\mathrm{p}=0,000)$. Usia, pendidikan, pekerjaan, penghasilan keluarga, dan informasi sebelumnya tidak berpengaruh secara signifikan terhadap pengetahuan dan keikutsertaan.

Simpulan: Kesimpulannya pendidikan kesehatan efektif dalam meningkatkan pengetahuan dan keikutsertaan pasutri dalam melakukan deteksi dini

Kata Kunci : deteksi dini, educator, keikutsertaan pasutri, suami, kanker leher rahim
\end{abstract}


The Role of the Husband as an Educator on Married Couples in Performing Early Detection of Cervical Cancer

\section{Abstract}

Background: Issues of women's health is still a task for the government and health workers, related to high maternal mortality rate, one of which is caused by cervical cancer. Efforts are being made to prevent cervical cancer is by early detection. By providing information through health education to motivate couples to early detection.

Objective: Research purposes is analyzing the role of husband and cervical cancer patients as educator of the knowledge and participation of couples in the early detection in health centers Karangmojo II and Semanu I Gunungkidul

Method: Methods Quasi-experimental design with pretest and posttest control group design. Selection of the sample using simple random sampling technique as much as 42 couples for the intervention group and 42 respondents for the control group. Health education as an intervention by her husband cervical cancer patients as educator using a pocket book and cadres use leaflet. Data were analyzed using $t$-test, chi-square, linear regression and binary logistic with siginifan level $\alpha=$ 0.05

Results: The result is increased knowledge and participation in the intervention group is higher than the control group after a given intervention $(p=0.000)$. Age, education, occupation, family income, and previous information did not significantly affect the knowledge and participation.

Conclusion: The conclusion is health education is effective in improving the knowledge and participation of couples in the early detection

Keywords : early detection, educator, participating couples, husband, cervical cancer

\section{PENDAHULUAN}

\section{Sustainable Development Goals}

(SDG's) yaitu pembangunan berkelanjutan

sebagai agenda pembangunan global untuk

periode 2016-2030, dengan tujuan SDG's yang

ke-3 adalah meningkatkan kesehatan yang baik

dengan target yang akan dicapai yaitu

mengurangi sepertiga kematian akibat

penyakit tidak menular (PTM). Kanker leher

rahim merupakan salah satu penyakit tidak

menular. Penyebab dari kanker leher rahim adalah infeksi dari Human Papilloma Virus

(HPV) yang onkogenik tipe 16 dan $18, \mathrm{HPV}$

E6/E7. Virus ini menginfeksi leher rahim melalui kontak seksual, berganti-ganti pasangan, aktivitas seksual dimulai pada usia dini.

International Agency for Research on Cancer (IARC) menyebutkan pada tahun 2012 terdaat 527.624 kasus baru dengan kanker leher rahim di alami oleh wanita diseluruh dunia dengan 14,1 juta kasus kanker baru yang muncul, pada tahun yang sama 8,2 juta wanita meninggal karena kanker. Hampir $85 \%$ 
kejadian tersebut terjadi di negara berkembang (Wittet and Tsu, 2008). Secara nasional, penyakit kanker pada penduduk semua umur di Indonesia tahun 2013 sebesar 1,4\% atau diperkirakan sekitar 347.792 orang. Prevalensu kanker di Indonesia paling tertinggi ada di provinsi DIY sebesar $4,1 \%$ (Kementerian Kesehatan RI, 2013).

Beberapa upaya yang telah dilakukan untuk mencegah terjadinya kanker leher rahim adalah dengan melakukan deteksi dini. Deteksi dini adalah tindkan yang dilakukan pada orang sehat dengan tanpa tanda gejala-gejala penyakit tertentu dengan tujuan untuk mengetahui terjadinya peningkatan resiko terhadap penyakit tertentu. Salah satu metode deteksi dini adalah dengan metode inspeksi visual asam astetat (IVA). Metode IVA adalah metode deteksi dini yang paling sederhana, yaitu dengan cara memberi larutan asam asetat/asam cuka pada leher rahim dan hasilnya dapat dilihat secara inspekulo dengan mata telanjang. WHO menyebutkan, bahwa deteksi dini dikatakan berhasil apabila bisa mencakup $80 \%$ dari populasi yang ditargetkan (WHO, 2002).

Pengalaman di negara maju menunjukkan bahwa program deteksi dini dapat menurunkan jumlah kasus baru kanker leher rahim sebesar 93\% melalui deteksi dini tahunan, 93-91\% dengan deteksi dini dua atau tiga tahun, $84 \%$ dengan deteksi dini lima tahunan dan $64 \%$ dengan deteksi dini 10 tahunan. Sedangkan di negara berkembang diperkirakan baru $5 \%$ perempuan yang telah melakukan deteksi dini (Silalahi, 2017). Faktor yang menyebabkan perempuan tidak bersedia melakukan deteksi dini adalah rasa takut bila ternyata hsilnya menyatakan bahwa mereka menderita kanker leher rahim, perasaan malu, khawatir atau cemas Rachmadahniar (2005).

Puskesmas Karangmojo II dan Semanu I merupakan salah satu puskesmas yang dapat melayani pemeriksaan deteksi dini dengan metode IVA. Selama ini puskesmas sudah banyak melakukan promosi kesehatan terkait deteksi dini serta melakukan jemput bola pada wanita yang sudah menikah dan belum pernah melakukan deteksi ini. Tetapi hal ini juga 
belum membuat wanita yang berada di wilayah

kerja puskesmas tersebut ingin melakukan deteksi dini.

Salah satu strategi untuk merubah keyakinan individu adalah dengan memberikan informasi melalui pendidikan kesehatan yang dapat meningkatkan pengetahuan dan keikutsertaan deteksi dini. Pendidikan kesehatan dapat diberikan menggunakan penyuluhan dengan menggunakan suami penderita kanker leher rahim sebagai educator dan kader. Pendidikan kesehatan menggunakan dukungan suami dapat meningkatkan keikutsertaan istri melakukan deteksi dini metode pap smear (Rachmadahniar, 2005). Pendidikan kesehatan oleh kader dan survivor juga dapat meningkatkan keikutsertaan deteksi dini (Harfouche et al., 2011).

Membangun kesadaran wanita untuk ikut serta dalam program deteksi dini tidak hanya diberikan melalui peningkatan pengetahuan wanitanya. Seorang suami atau pria berpotensi untuk dilibatkan dalam meningkatkan program deteksi dini kanker leher rahim, karena suami atau pasangan merupakan motivator yang dapat diharapkan dukungannya untuk memberikan penguatan pribadi bagi pasangannya atau wanita agar berperilaku sehat (Rachmadahniar, 2005). Dalam hal ini, peneliti melakukan intervensi pendidikan kesehatan menggunakan suami penderita kanker leher rahim sebagai educator dan kader untuk mengetahui pengaruhnya terhadap pengetahuan dan keikutsertaan pasangan suami istri (pasutri) melakukan deteksi dini di Puskesmas Karangmojo II dan Semanu I Kabupaten Gunungkidul, Yogyakarta.

\section{METODE}

$$
\text { Jenis peneltian adalah Quasi }
$$

Ekxperiment dengan desain pretest-posttest control group design. Penelitian ini dilakukan pada bulan Maret tahun 2019 di wilayah kerja Puskesmas Karangmojo II dan Semanu I kabupaten Gunungkidul, Yogyakarta. Dengan waktu pengukuran sebanyak empat kali yaitu pretest pada minggu pertama, posttest-I pada kedua I, posttest-II pada minggu ketiga, dan posttest-III pada minggu keempat. Populasi 
Dinamika Kesehatan Jurnal Kebidanan dan Keperawatan Vol 10 No. 2 Desember 2019 ( ISSN: 2086-3454 EISSN: 2549-4058)

url: http://ojs.dinamikakesehatan.unism.ac.id DOI: https://doi.org/10.33859/dksm.v10i2

Peran Suami Sebagai Educator Pada Pasutri Dalam Melakukan Deteksi Dini Kanker Leher Rahim

dalam penelitian ini adalah pasutri yang berasa wilayah kerja Puskesmas Karangmojo II dan

Semanu I. Sampel dalam penelitian ini berjumlah 84 pasutri yang dibagi dua menjadi 42 responden pasutri di Puskesmas Karangmojo II sebagai kelompok eksperimen dan 42 responden pasutri di Puskesmas Semanu I sebagai kelompok kontrol. Peneliti melakukan pengambilan sampel sengan teknik simple random sampling. Pendidikan kesehatan diberikan kepada responden sebanyak tiga kali dengan selang waktu satu minggu setiap kali diadakan pendidikan kesehatan. Pendidikan kesehatan oleh suami penderita kanker leher rahim sebagai educator menggunakan alat bantu buku saku yang diadaptasi dari Departemen Kesehatan RI (2009) 'Buku Saku Pencegahan Kanker Leher Rahim dan Kanker Payudara" berisi penjelasan tentang kanker leher rahim dan metode deteksi dini. Sedangkan pendidikan kesehatan oleh kader menggunkan alat bantu leaflet yang digunakan oleh puskesmas. Pengetahuan diukur dengan kuesioner yang telah diuji validitas dan reliabilitasnya oleh peneliti sebelumnya denan hasil alpha variabel pengetahuan $=0,09$ (Purnamaningrum, 2011) . Keikutsertaan dinilai dengan memberikan kesioner lembar keikutsertaan responden melakukan deteksi dini dengan metode IVA untuk mengetahui responden telah melakukan deteksi dini atau tidak. Analisa data dengan uji univariat, uji bivariat, dan uji multivariat. Uji normalitas data dilakukan dengan menggunakan uji Shapiro-Wilk dengan p>0,05 berdistribusi normal. Analisa data untuk menganalisis perbedaan peningkatan pengetahuan masing-masing kelompok perlakuan dengan menggunakan uji paired $t$ test, sedangkan untuk menganalisis selisih rerata pengetahuan kedua kelompok perlakuan menggunakan uji independent t-test dengan tingkat kemaknaan $\quad \alpha=0,05$. Analisis keikutsertaan pasutri dalam melakukan deteksi dini dengan uji Chi Square. Uji multivariat untuk mengetahui pengaruh pendidikan kesehatan terhadap pengetahuan dengan analisis regresi linier, sedangkan pengaruh pendidikan kesehatan terhadap keikutsertaan dengan analisis regresi binary logistik. 
Penelitian ini telah mendapatkan persetujuan etik dari Komisi Etik Penelitian Kesehatan

Politeknik Kesehatan Kemenkes Yogyakarta.

\section{HASIL}

Data karakteristik responden pada Tabel 1 didapatkan bahwa usia responden kelompok eksperimen adalah <35 tahun sebanyak 24 orang $(57,1), 19$ orang berpendidikan dasar $(45,2 \%)$ dan berpendidikan menengah sebanyak 19 orang $(45,2 \%)$, bekerja sebanyak 29 orang $(69 \%)$, berpenghasilan <Rp1.454.200,- sebanyak 31 orang $(73,8 \%)$, dan belum pernah mendapatkan informasi sebelumnya sebanyak 26 responden (61,9\%). Pada kelompok kontrol, usia responden paling banyak >35 tahun sebanyak 26 orang $(61,9 \%)$, berpendidikan rendah sebanyak 21 orang (50\%), responden bekerja sebanyak 28 orang $(66,7 \%)$, berpenghasilan $<\mathrm{Rp} 1.454 .200,-$ sebanyak 31 orang $(73,8 \%)$, dan belum pernah mendapatkan informasi sebelumnya sebanyak 22 orang $(52,4 \%)$. Karakteristik responden berdasarkan usia, pendidikan, pekerjaan, penghasilan keluarga, dan informasi sebelumnya pada kedua kelompok adalah homogen, dengan $p>0,05$. Rata-rata pretest pengetahuan pada kelompok eksperimen yaitu 46,5, naik pada posttest 1 menjadi 63,6 , pada posttest2 mengalami kenaikan menjadi 73,5 , dan pada posttest3 menjadi 83,9. Sedangkan pada kelompok kontrol nilai rata-rata pengetahuan pretest 45 , naik menjadi 63,4 pada posttest1, pada posttest 2 menjadi 68,1 , dan pada posttest 3 menjadi 73,5. Keikutsertaan pasutri melakukan deteksi dini pada kelompok eksperimen posttest1 8 orang melakukan

Tabel 1.Karakteristik Responden

\begin{tabular}{|c|c|c|c|c|c|}
\hline & \multicolumn{2}{|c|}{$\begin{array}{c}\text { Eksperimen } \\
(n=42)\end{array}$} & \multicolumn{2}{|c|}{ Kontrol $(n=42)$} & \multirow{2}{*}{$\begin{array}{c}p- \\
\text { value } \\
*\end{array}$} \\
\hline & n (\%) & $\begin{array}{c}\text { Mea } \\
\text { n } \\
\pm \text { SD } \\
\end{array}$ & $\mathrm{n}(\%)$ & $\begin{array}{c}\text { Mea } \\
\text { n } \\
\pm \text { SD } \\
\end{array}$ & \\
\hline \multicolumn{6}{|l|}{ Karakteristik } \\
\hline $\begin{array}{l}\text { Usia : } \\
<35 \text { tahun } \\
>35 \text { tahun }\end{array}$ & $\begin{array}{r}24(57,1 \\
) \\
18(42,9 \\
) \\
\end{array}$ & & $\begin{array}{r}16(38,1 \\
) \\
26(61,9 \\
) \\
\end{array}$ & & 0,081 \\
\hline $\begin{array}{l}\text { Pendidikan: } \\
\text { Dasar } \\
\text { Menengah } \\
\text { Tinggi }\end{array}$ & $\begin{array}{r}19(45,2 \\
) \\
19(45,2 \\
) \\
4(9,5) \\
\end{array}$ & & $\begin{array}{r}21(50,0 \\
) \\
16(38,1 \\
5(11,9) \\
\end{array}$ & & 0,791 \\
\hline $\begin{array}{l}\text { Pekerjaan : } \\
\text { Tidak Bekerja } \\
\text { Bekerja }\end{array}$ & $\begin{array}{r}13(31,0 \\
) \\
29(69,0 \\
) \\
\end{array}$ & & $\begin{array}{r}14(33,3 \\
) \\
28(66,7 \\
) \\
\end{array}$ & & 0,815 \\
\hline $\begin{array}{l}\text { Penghasilan : } \\
<\text { Rp1.454.200,- } \\
\geq \operatorname{Rp} 1.454 .200,-\end{array}$ & $\begin{array}{r}31(73,8 \\
) \\
11(26,2 \\
) \\
\end{array}$ & & $\begin{array}{r}31(73,8 \\
) \\
11(26,2 \\
) \\
\end{array}$ & & 1,000 \\
\hline $\begin{array}{l}\text { Informasi } \\
\text { Sebelumnya : } \\
\text { Belum pernah } \\
\text { Sudah Pernah }\end{array}$ & $\begin{array}{r}26(61,9 \\
) \\
16(38,1 \\
) \\
\end{array}$ & & $\begin{array}{r}22(52,4 \\
) \\
20(47,6 \\
) \\
\end{array}$ & & 0,378 \\
\hline
\end{tabular}


Dinamika Kesehatan Jurnal Kebidanan dan Keperawatan Vol 10 No. 2 Desember 2019 ( ISSN: 2086-3454 EISSN: 2549-4058)

url: http://ojs.dinamikakesehatan.unism.ac.id DOI: https://doi.org/10.33859/dksm.v10i2

Peran Suami Sebagai Educator Pada Pasutri Dalam Melakukan Deteksi Dini Kanker Leher Rahim

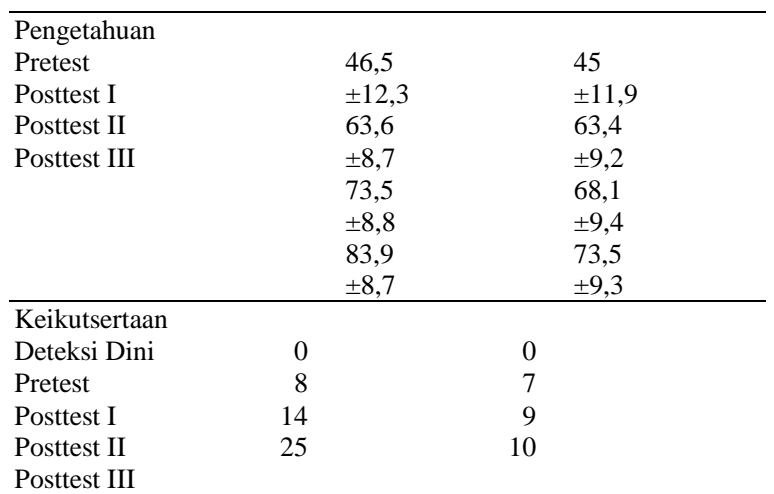

Hasil uji bivariat didahului dengan melakukan uji normalitas dan didapatkan variabel pengetahuan pada kelompok eksperimen dan kelompok kontrol berdistribusi normal dengan nilai masing-masing $\mathrm{p}>0,05$. Berdasarkan tabel 2 uji bivariat pada variabel pengetahuan dilakukan dengan uji paired t-test, didapatkan pada masing-masing kelompok memiliki nilai $\mathrm{p}<0,05$ yang berarti ada peningkatan pengetahuan yang bermakna pada kelompok eksperimen dan kelompok kontrol (pretestposttest1, pretest-posttest2, pretest-posttest3).

Tabel 2 Analisis Perbedaan Rata-rata Pengetahuan Masing-masing Kelompok

\begin{tabular}{|c|c|c|}
\hline Kelompok & Pengetahuan & $\begin{array}{c}p- \\
\text { value }\end{array}$ \\
\hline \multirow[t]{3}{*}{ Eksperimen } & $\begin{array}{l}\text { Pretest- } \\
\text { posttest } 1\end{array}$ & 0,000 \\
\hline & $\begin{array}{l}\text { Pretest- } \\
\text { posttest } 2\end{array}$ & 0,000 \\
\hline & $\begin{array}{l}\text { Pretest- } \\
\text { posttest } 3\end{array}$ & 0,000 \\
\hline \multirow[t]{3}{*}{ Kontrol } & $\begin{array}{l}\text { Pretest - } \\
\text { posttest } 1\end{array}$ & 0,000 \\
\hline & $\begin{array}{l}\text { Pretest- } \\
\text { posttest } 2\end{array}$ & 0,000 \\
\hline & $\begin{array}{l}\text { Pretest - } \\
\text { posttest } 3\end{array}$ & 0,000 \\
\hline
\end{tabular}

Pada analisis independent t-test untuk mengetahui selisih rerata kedua kelompok berdasarkan tabel 3, didapatkan pada posttest1 selisih mean kedua kelompok sebesar 1,3 dengan $\mathrm{p}>0,05$ yang berarti tidak ada perbedaan peningkatan yang bermakna antara kedua kelompok. Pada posttest 2 selisih mean kedua kelompok sebesar 3,9 dengan $\mathrm{p}>0,05$ yang berarti tidak ada perbedaan peningkatan yang bermakna antara kedua kelompok. Sedangkan pada posttest $3 \quad \mathrm{p}<0,05$, ada perbedaan peningkatan yang bermakna antara kedua kelompok.

Tabel 3 Analisis Selisih Rerata Pengetahuan Kedua Kelompok

\begin{tabular}{|c|c|c|c|c|}
\hline Kelompok & & $\begin{array}{l}\text { Selisih } \\
\text { Mean }\end{array}$ & $\begin{array}{c}\text { Perbedaan } \\
\text { selisih } \\
\text { rerata }\end{array}$ & $\begin{array}{c}p- \\
\text { value }^{*}\end{array}$ \\
\hline Eksperimen & Posttest & 17,1 & \multirow[b]{2}{*}{1,3} & \multirow[b]{2}{*}{0,62} \\
\hline Kontrol & 1 & 18,4 & & \\
\hline Eksperimen & Posttest & 27,0 & \multirow{2}{*}{3,9} & \multirow{2}{*}{0,15} \\
\hline Kontrol & 2 & 23,1 & & \\
\hline Eksperimen & Posttest & 37,3 & \multirow{2}{*}{8,8} & \multirow{2}{*}{0,00} \\
\hline Kontrol & 3 & 28,5 & & \\
\hline
\end{tabular}

Hasil uji Chi Square pada tabel 4, keikutsertaan pasutri pada pretest-posttest1 dengan $\mathrm{p}>0,05$, yang berarti tidak ada hubungan yang bermakna pada kedua 
Dinamika Kesehatan Jurnal Kebidanan dan Keperawatan Vol 10 No. 2 Desember 2019 ( ISSN: 2086-3454 EISSN: 2549-4058)

url: http://ojs.dinamikakesehatan.unism.ac.id DOI: https://doi.org/10.33859/dksm.v10i2

Peran Suami Sebagai Educator Pada Pasutri Dalam Melakukan Deteksi Dini Kanker Leher Rahim

kelompok perlakukan. Pada pretest-posttest2 dengan $p>0,05$ yang berarti tidak ada hubungan yang bermakna pada kedua kelompok perlakuan. Sedangkan pada pretestposttest3 $\mathrm{p}<0,05$, ada hubungan yang bermakna pada kedua kelompok perlakuan

Tabel 4 Hubungan Keikutsertaan Deteksi Dini

\begin{tabular}{lcc}
\hline Kelompok & Keikutsertaan & p-value* \\
\hline Eksperimen & Pretest-posttest 1 & 0,500 \\
Kontrol & Pretest - posttest 2 & 0,164 \\
& Pretest - posttest 3 & 0,001 \\
\hline
\end{tabular}

*) Uji Chi Square, 0,05 level of significant

Hasil uji multivariat pada tabel 5 didapatkan bahwa ada pengaruh narasumber penyuluhan terhadap pengetahuan dengan nilai $\mathrm{p}<0,05$ dan besarnya pengaruh narasumber penyuluhan terhadap pengetahuan responden sebesar $25,2 \%$.

Tabel 5. Pengaruh Narasumber Penyuluhan terhadap Pengetahuan

\begin{tabular}{lccc}
\hline \multicolumn{1}{c}{ Variabel } & $\mathbf{B}$ & $\mathbf{X}_{\mathbf{2}}$ & p-value $^{*}$ \\
\hline Konstanta & 73,571 & 52,783 & 0,000 \\
Narasumber & 10,357 & 5,254 & 0,000 \\
R square & 0,252 & & \\
& & \\
\hline *) Uji Regresi Linier, & 0,05 level of significant
\end{tabular}

Hasil uji multivariat pada tabel 6, bahwa ada pengaruh narasumber penyuluhan terhadap keikutsertaan pasutri melakukan deteksi dini dengan $\mathrm{p}<0,05$, yang berpengaruh sebesar
$17 \%$ oleh narasumber penyuluhan terhadap keikutsertaan pasutri..

Tabel 6 Pengaruh Narasumber Penyuluhan terhadap Keikutsertaan Deteksi Dini

\begin{tabular}{lccc}
\hline \multicolumn{1}{c}{ Kelompok } & B & $\operatorname{Exp}(\mathbf{B})$ & p-value \\
\hline Narasumber & 1,549 & 4,706 & 0,001 \\
Konstanta & $-1,163$ & 0,313 & 0,001 \\
R square & 0,170 & & \\
Percentage Correct & 67,9 & & \\
\hline
\end{tabular}

\section{PEMBAHASAN}

Hasil penelitian menunjukkan tidak ada perbedaan pengetahuan yang signifikan dengan nilai $\mathrm{p}>0,05$ sebelum dan sesudah diberikan penyuluhan (pretest-posttest1, pretest-posttest2) pada kelompok eksperimen dan kelompok kontrol. Tetapi ada perbedaan pengetahuan yang dignifikan denan nilai $\mathrm{p}<0,05$ pada pretest-posttest3. Peningkatan rata-rata pengetahuan lebih besar pada kelompok eksperimen dibandingkan kelompok kontrol. Pengetahuan adalah hasil dari memperoleh informasi yang didapat melalui penginderaan terhadap suatu objek (Dahlan, 2013). Pengetahuan tentang kanker leher rahim dan deteksi dini dengan metode IVA merupakan domain yang penting untuk terbentuknya tindakan berupa keikutsertaan pasutri dalam melakukan deteksi dini. 
Penelitian yang dilakukan oleh Chinwe \& Udenebonta (2015), responden penelitian relatif memiliki pengetahuan yang baik tentang kanker leher rahim setelah diberikan pendidikan kesehatan. Pengetahuan dapat meberi pengaruh positif dan membentuk keyakinan sehingga seseorang dapat berperilaku menurut keyakinannya yang diperoleh melalui pendidikan kesehatan. Keberhasilan pendidikan kesehatan dipengaruhi oleh beberapa faktor, salah satunya adalah penyuluhan oleh tenaga kesehatan dan non kesehatan. Pada penelitian ini penyuluhan dilakukan oleh suami penderita kanker leher rahim sebagai educator dan kader. Penelitian yang dilakukan oleh Wahyuni (2011) dengan melibatkan keluarga/partner dapat memberikan dukungan yang positif terhadap pengetahuan tentang kanker leher rahim.

\section{Pendidikan kesehatan memberi} pengaruh yang baik kepada masyarakat untuk meningkatkan kepercayaan kesehatan mereka, sehingga masyarakat terdorong untuk mau melakukan deteksi dini karena mereka lebih menyadari bahwa mereka berisiko terkena kanker leher rahim. Setelah diberikan perlakuan, kelompok eksperimen lebih banyak yang melakukan deteksi dini dibandingkan kelompok kontrol. Pendidikan kesehatan adlaa praktik kesehatan yang dikaukan untuk merubah perilaku individu, kelompok, dan populasi yang lebih besar ke arah perilaku yang lebih baik, dan informasi yang benar akan memberikan stimulsi yang positif tentang perilaku hidup sehat (Silalahi, 2017). Pendidikan kesehatan pada penelitian ini sangat bermanfaat bagi responden, karena responden menjadi lebih memahami tentang kanker leher rahim dan manfaat deteksi dini, responden dalam penelitian ini belum pernah melakukan deteksi dini dalam bentuk apapun sebelumnya.

\section{SIMPULAN}

Pendidikan kesehatan menggunakan suami penderita kanker leher rahim sebagai educator dan kader efektif dalam meningkatkan pengetahuan dan keikutsertaan pasutri melakukan deteksi dini di wilayah kerja Puskesmas Karangmojo II dan Semanu I 
Kabupaten Gunungkidul, Yogyakarta. Bagi

Puskesmas Karangmojo II dan Semanu I perlu mengikutsertakan suami penderita kanker leher rahim sebagai educator dalam memberikan pendidikan kesehatan sebagai salah satu upaya promosi kesehatan untuk meningkatkan keikutsertaan deteksi dini. Peneliti selanjutnya dapat melakukan penelitian dengan menggunakan narasumber suami yang lebih banyak lagi.

\section{UCAPAN TERIMAKASIH}

Penulis mengucapkan terimakasih kepada Yayasan STIKes Eka Harap Palangkaraya yang telah membantu secara moril maupun materil selama studi dan penyelesaian penelitian, para dosen pembimbing dan dosen penguji, tim penelitian dari Puskesmas Karangmojo II dan Semanu I, serta seluruh responden yang telah terlibat dalam penelitian ini.

\section{DAFTAR PUSTAKA}

Chinwe. and Udenebonta (2015) 'Impact of Health Education on Knowledge, Attitude and Practice of Cervical Cancer Screening Among Secondary School Teachers in Enugu State', J Women's Health Care. Available at: http://doi.org/10.4172/21670420.1000241 .

Dahlan, M. (2013) Statistik untuk Kedokteran dan Kesehatan: Deskriptif, Bivariat dan Multivariat dilengkapi Aplikasi dengan Menggunakan SPSS. Jakarta: salemba medika.

Departemen Kesehatan RI (2009) Buku Saku Pencegahan Kanker Leher Rahim dan Kanker Payudara.

Harfouche, F. G., Jandorf, L. and Gage, E. (2011) 'Esperanza y Vida: Training Lay Health Advisors and Cancer Survivors to Promote Breast and Cervical Cancer Screening in Latinas', pp. 219-227. doi: 10.1007/s10900-010-9300-3.

Kementerian Kesehatan RI (2013) Riset Kesehatan Dasar, Jakarta: Badan Penelitian dan Pengembangan Kesehatan Departemen Kesehatan Republik Indonesia. doi: 10.1007/s13398-014-0173-7.2.

Purnamaningrum, Y. E. (2011) Efektivitas Pendidikan Kesehatan oleh Lay Health Workers (LHW's) dalam Meningkatkan Kesertaan Skrining Kanker Leher Rahim dengan Metode Inspeksi Visual Asam Asetat (IVA) pada Wanita Usia 25-50 Tahun du Kabupaten Sleman. Gadjah Mada Yogyakarta.

Rachmadahniar (2005) Dukungan sosial suami terhadap partisipasi wanita dalam Program Skrining Kanker Leher Rahim di Biro Konsultasi Kanker Yayasan Kucala Yogyakarta. Universitas Gadjah Mada. 
Silalahi, V. (2017) Efektivitas Pendidikan Kesehatan Menggunakan Media Audiovisual dan Booklet Terhadap Perilaku Wanita Dalam Melakukan Skrining Inspeksi Visual Dengan Asam Asetat (IVA) Untuk Deteksi Dini Kanker Serviks. Universitas Gadjah Mada.

Wahyuni, S. (2011) Efektifitas Edukasi MEtode Wish and Drive Terhadap Perilaku Deteksi Dini KAnker Serviks di Kecamatan Ngampel Kabupaten Kencal Jawa Tengah. Universitas Indonesia.

Wittet, S. and Tsu, V. (2008) 'Cervical cancer prevention and the Millennium Development Goals', Bulletin of the World Health Organization, 86(6), pp. 488-490. doi: 10.2471/BLT.07.050450.

World Health Organization (2002) 'Cervical Cancer Screening in Developing Countries'. Available at: http://www.who.int/cancer/media/en/ca ncer_cervical_37321.pdf. 